\section{Regional vs general anaesthesia in orthopaedics}

\section{N. Buckley MD FRCPC}

Regional anaesthesia may indeed "have more to offer orthopaedic surgery than any other surgical specialty." Certainly the anaesthesia options for peripheral limb surgery are greater than for some other operations. However, there is a persistent, albeit largely unsupported, belief that regional anaesthesia is somehow "better" than general anaesthesia. At least one author goes so far as to refer in his discussion to "... the usual advantages of regional anesthesia ..." without describing them. ${ }^{2}$ Surgeons and internists are famous for the ubiquitous solution to all perioperative risks - "they'd be OK for a spinal ...". However, the benefits of regional anaesthesia are much more clearly defined in our perception than in the literature, and I would like to address this issue.

There are a variety of reasons for choosing a given anaesthetic technique. Firstly, a technique could be chosen simply because we know it; it may be a favourite, familiar technique, or a less familiar technique chosen to maintain competence/experience, or to teach. This applies to all techniques and it may be that perhaps one should consider scheduling a rotation of techniques to maintain a breadth of familiarity and competence.

Secondly, a technique may be chosen for some specific intraoperative effect such as sympathectomy, or the desire for patient cooperation during surgery. The technique may also avoid the need for some manoeuvre which would prove difficult or increase the potential for complications - for example, regional techniques are typically avoided in patients with coagulopathy, while it may be advantageous to use a technique which avoids having to intubate the trachea in a patient with a difficult airway.

The most compelling practice arguments come from the claim of improved outcomes, and avoidance or reduction of specific morbidity. Unfortunately, these are also the areas where the published evidence is least supportive. Although intraoperative adverse events may be reduced during regional anaesthesia, ${ }^{3}$ this may not translate into changes in outcome. A meta-analysis of published literature comparing regional and general anaesthesia in a wide variety of surgeries found reduction in DVT to be the only advantage of regional anaesthesia. ${ }^{4}$ Claims of reduced morbidity have been made in the areas of metabolic function, immunological function, pulmonary function, incidence of deep venous thrombosis and maintenance of cognitive function. Discussions also focus around the use of regional versus general anaesthesia in specific age groups, to reduce blood loss, or avoid nausea and vomiting.

\section{Metabolic function}

Many of the investigations into the metabolic effects of regional blockade relate to pelvic or abdominal surgery, and may have limited relevance to orthopaedics. Nonetheless, a brief review is in order. Intraoperatively, epidural blockade with local anaesthesia attenuates the hyperglycaemic response to surgery; ${ }^{5}$ and has reduced the usual increase in cortisol. ${ }^{6}$ This inhibition carries over into the postoperative period, if the blockade is maintained; however, there is still an attenuation of the insulin response to hyperglycaemia in the postoperative period, and this seems unaffected by the choice of anaesthetic. ${ }^{7}$ Use of extradural diamorphine is associated with a reduction in plasma glucose and cortisol concentrations. ${ }^{8}$ Body heat is redistributed to the periphery during epidural anaesthesia, resulting in a reduction in core temperature. ${ }^{9,10}$ It may be that blunting of the cortisol response also attenuates the increased metabolic activity necessary to effect a return to normal body temperature. In fact, a global reduction in nitrogen loss was recorded over a five-day period after epidural anaesthesia compared to general anaesthesia with halothane, ${ }^{11}$ indicating a reduced catabolic process. Lipolysis has also been shown to be reduced in the perioperative $24 \mathrm{hr}$, an effect which largely disappeared after the epidural analgesia used postoperatively was allowed to wear off. ${ }^{12}$

In one specifically orthopaedic study, patients having general anaesthesia had lower temperatures than those receiving regional anaesthesia on PACU admission; this may have been due to the greater duration of the GA procedures; ${ }^{13}$ other specific metabolic markers were not measured.

\section{Immune function}

In examining the effect of surgery and anaesthesia on lymphocyte transformation and leucocyte count, Cullen and van Belle ${ }^{14}$ found suppression which they felt was

From McMaster University, Hamilton, Ontario. 
proportional to the degree of surgical trauma, and independent of the type of anaesthesia whether regional or general. Interpretation of that study was complicated by the variety of operations and the inclusion of regional anaesthetics given for diagnosis and treatment of chronic pain states.

Epidural anaesthesia for hysterectomy eliminated an increase in plasma glucose and cortisol concentrations seen in the general anaesthesia group; nonetheless, acute phase proteins underwent similar changes in both groups. ${ }^{15}$ Delayed hypersensitivity was not differentially affected by epidural or general anaesthetics ${ }^{16}$ after abdominal surgery, but after TURP spinal anaesthesia was associated with less reduction in lymphocyte numbers, and maintenance of response to mitogens. ${ }^{17}$ During total hip arthroplasty, general anaesthesia with halothane or isoflurane was found to inhibit neutrophil chemotaxis, ${ }^{18}$ while spinal anaesthesia did not.

In his Canadian Anaesthesia Journal editorial, Moudgil $^{19}$ has clearly outlined the difficulties involved in in vitro and in vivo assessment of immune function, and the complexity of the influences in the clinical situation. At this time, although there certainly is evidence of interaction among anaesthetics, surgery and the immune system, the precise nature and extent of these influences remain uncertain.

\section{Pulmonary function}

Pulmonary complications are not generally considered to be a major problem in peripheral orthopaedic procedures, with the exception of pulmonary thromboembolic complications (addressed separately). Nonetheless, in patients with problems of respiratory drive (e.g., sleep apnoea, ex-premature infants still at increased risk for druginduced apnoea), there may be specific indications for the use of regional anaesthesia to avoid the use of sedative anaesthetic/analgesic agents. Reports of advantages, however, are still largely at the level of extended practice observations rather than controlled comparative studies. ${ }^{20}$ Studies reporting maintenance of or early return of lung volumes usually focus on abdominal procedures, ${ }^{21-23}$ and do not uniformly demonstrate a benefit with the use of regional anaesthesia or analgesia techniques. One study compares spinal anaesthesia for total hip or knee arthroplasty to general anaesthesia for total hip arthroplasty. ${ }^{24}$ Although the spinal group displayed an increased $\mathrm{A}-\mathrm{aO}_{2}$ gradient, and reduced $\mathrm{PaO}_{2}$, this may have been due to respiratory depression from subarachnoid morphine administered to the spinal group; it may also reflect differences in pulmonary microembolic phenomena between the hip and knee procedures.

More typical observations are those of Hole et al. ${ }^{25}$ and McKenzie et al. ${ }^{26}$ Hole found that on the first and third postoperative days, $\mathrm{PaO}_{2}$ was higher in patients receiving epidural anaesthesia for total hip arthroplasty than in patients receiving general anaesthesia. McKenzie, in patients undergoing repair of hip fractures, found a significant immediate decline in $\mathrm{PaO}_{2}$ following general but not after spinal anaesthesia. However, there is as yet no evidence that these immediate perioperative changes have any influence on patient outcome, and it would be premature to claim superiority of one technique over another.

\section{Deep venous thrombosis}

Considerable effort has gone into examining the reduction in deep venous thrombosis associated with the use of regional anaesthesia, particularly in the repair of hip fracture and total hip replacement. The reductions are variously attributed to maintenance of spontaneous ventilation and thus unimpeded venous return, ${ }^{27}$ increased deformability of red cells during subarachnoid block, ${ }^{28}$ maintenance of fibrinolytic activity, ${ }^{29}$ or a combination of the above. ${ }^{30}$ Leg blood flow has been examined during and after spinal and general anaesthesia but does not have a clear influence. ${ }^{31}$ The same authors later found general anaesthesia to be significant in a logistic regression model predicting occurrence of DVT after total hip replacement, ${ }^{32}$ but in total knee replacement, neither Mitchell et al. ${ }^{33}$ nor Stafford-Smith et al. ${ }^{34}$ found any difference in DVT for patients receiving GA plus antithrombotic prophylaxis vs epidural anaesthetic with prophylaxis which began postoperatively.

The issue of adequate prophylaxis is probably vital. Prins and Hirsh ${ }^{35}$ reviewed the evidence for antithrombotic effect of regional anaesthesia and while not disputing the finding of a reduction in DVT, they commented that the studies reviewed all examined patients who did not receive antithrombotic prophylaxis. The incidences of DVT, while reduced with regional anaesthesia, were unacceptably high at $29-40 \%$. Their penultimate comment is that "regional anaesthesia should not be regarded as a substitute for effective primary antithrombotic prophylaxis."

A subsequent study by Jorgensen ${ }^{36}$ incorporating compressive elastic stockings following total knee replacement found an incidence of $17 \%$ DVT in the epidural group, compared with $59 \%$ in the GA group.

\section{Delirium and dementia}

Deterioration of mental function is a major concern for elderly patients who are in full possession of their faculties. Complications range from loss of concentration, depression or minor memory loss through dementia to delirium. The aetiology of mental dysfunction is complex and may relate to pre-existing disease, perioperative complications, hospitalization, and the effect of analgesics 
or other medications administered postoperatively. The reported incidence of postoperative delirium varies from $7 \%$ to $25 \% .{ }^{37}$ Hole et al ${ }^{25}$ found a substantial reduction in mental function in the general anaesthesia group and not the epidural group after hip replacement, with changes persisting for several months. However, Ghoneim found no evidence that choice of anaesthetic has any influence on mental function either immediately after surgery or at three months. ${ }^{37}$ There was an immediate decline in word recognition $24 \mathrm{hr}$ after hip arthroplasty under spinal anaesthesia which did not occur after general anaesthesia, but at 48 hours and one week later there was no difference. ${ }^{38}$ Even after prostatectomy, an operation which is considered to have a high risk for postoperative cognitive dysfunction, Asbjorn et al. ${ }^{39}$ found no difference between epidural or general anaesthesia; both groups had declines in performance on psychological testing at the fourth postoperative day which subsequently resolved.

In patients who underwent bilateral total knee arthroplasties under epidural anaesthesia, $41 \%$ developed delirium, most within 48 hours of surgery. There was no difference between two analgesic groups: one receiving continuous bupivacaine plus fentanyl and the other fentanyl alone (via the epidural). ${ }^{40}$ Although this incidence seems quite high, diagnosis was based on DSM III $R$ criteria applied by study investigators blinded to group. Only half of the patients who met these diagnostic criteria had been identified by nurses or physicians as delirious. This incidence may reflect some intrinsic risk associated with bilateral total knee replacement. In a study specifically examining memory and IQ scores following total knee arthroplasty in elderly patients, there was no difference between spinal or general anaesthesia groups at a three-month follow-up. ${ }^{4 !}$

Attempting to identify predictors of postoperative confusion in patients with hip fractures, Berggren et al. ${ }^{42}$ found that a history of depression, or preoperative use of medications with anticholinergic effects (e.g., tricyclics, neuroleptics, drugs aimed at bladder dysfunction) were predictors, while anaesthetic technique (epidural or GA with halothane) was not.

\section{Anaesthesia for the aged}

Santos and Gelperin ${ }^{43}$ noted in 1975 that surgical mortality for elderly patients had declined substantially, and that the elderly should not be denied surgery because of their temporal disadvantages. Many subsequent studies have focused on the identification of anaesthetic techniques which will further reduce morbidity and mortality in the elderly.

Despite some early suggestions that spinal anaesthesia was associated with lower mortality, ${ }^{44}$ a number of sub- sequent studies has failed to support this finding ${ }^{45-50}$ in patients undergoing repair of hip fracture or total hip arthroplasty. In part this apparent change in outcome reflects the use of longer follow-up times. There still seems to be a short-term reduction in mortality, with convergence of total mortality by about two to three months postoperatively.

\section{Regional anaesthesia for paediatrics}

Although refresher courses and abstracts routinely comment on the possible uses of regional anaesthesia in children, much less exists in the literature examining outcome following various anaesthetic techniques. Many of the factors associated with morbidity and mortality in adults and the elderly seem to be less common in the paediatric population.

However, use of regional anaesthetic techniques, when they can be achieved in a safe and acceptable fashion, may provide good postoperative analgesia with less need to resort to narcotic analgesics following some outpatient operations, and less nausea and vomiting. ${ }^{51}$

\section{Blood loss}

Reduced intraoperative blood loss is frequently presented as an advantage of regional anaesthesia for total hip arthroplasty and repair of fractured hips. However, only one study ${ }^{44}$ of five reviewed here $e^{26,30,44,47}$ found a reduction in intraoperative blood loss during repair of fractured hips. In total hip arthroplasty, three studies reviewed ${ }^{28,29,52}$ found significant reductions in intraoperative blood loss while one ${ }^{25}$ showed no change.

As with DVT, positive pressure ventilation may play a role in altering intraoperative blood loss during total hip replacement. Patients breathing spontaneously during general anaesthesia had total perioperative blood loss comparable to patients receiving spinal anaesthesia, and both were less than a group receiving anaesthesia with positive pressure ventilation. ${ }^{52}$ I was unable to find a direct comparison of general anaesthesia with controlled hypertension to spinal or epidural anaesthesia. No advantage was found for total knee arthroplasty ${ }^{33,34}$ which is not surprising in view of the frequent intraoperative use of a tourniquet.

\section{Nausea and vomiting}

Although the incidence of nausea and vomiting is less after orthopaedic procedures than after abdominal or gynaecological surgery, ${ }^{54}$ a reduction in nausea and vomiting is frequently offered as an advantage of regional anaesthesia. At least one study of total hip arthroplasty found this to be the case. ${ }^{25}$ Interestingly enough, there has also been reported a variability between hospitals in such adverse events, ${ }^{55,56}$ and given the other potential 
complicating factors such as cyclic hormonal variations, ${ }^{57,58}$ the potential design complications for an appropriate study become quite daunting.

\section{Conclusion}

It becomes difficult to develop a cogent argument (from the literature regarding patient outcome) for regional anaesthesia in preference to general anaesthesia for orthopaedic surgery. For deep venous thrombosis, it may be that the attendant medical care of the patient should be altered rather than the anaesthetic technique. Advantages of regional anaesthesia may be short-lived, and overwhelmed by the myriad of other factors coming into play, as with blood loss and perioperative delirium. Even nausea and vomiting are not clearly reduced by the use of the techniques. The persistence of the belief in the superiority of regional anaesthesia may represent a case of our unwillingness to "abandon a perfectly good theory simply because it is wrong," or it may be that we simply have not asked the appropriate question to elucidate a common impression. This latter remains a challenge.

\section{References}

1 McKenzie PJ, Loach AB. Local anaesthesia for orthopaedic surgery. Br J Anaesth 1986; 58: 779-89.

2 Mitchell EI, Murphy FL, Wyche MQ Torg JS. Interscalene brachial plexus block anesthesia for the modified Bristow procedure. Am J Sports Med 1982; 10: 79-82.

3 Cohen JA. Fewer adverse occurrences during regional than general anaesthesia. Can J Anaesth 1990; 37: 584.

4 Sorensen RM, Pace NL. Mortality and morbidity of regional vs. general anesthesia: a meta analysis. Anesthesiology 1991; 75: A-1053.

5 Houghton A, Hickey JB, Ross SA, Dupre J. Glucose tolerance during anaesthesia and surgery. Comparison of general and extradural anaesthesia. Br J Anaesth 1978; 50: 495-9.

6 Jensen $\mathrm{CH}$, Berthelsen P, Kuhl C, Kehlet H. Effect of epidural analgesia on glucose tolerance during surgery. Acta Anesthesiol Scand 1980; 24: 472-4.

7 Buckley FP, Kehlet H, Brown NS, Scott DB. Postoperative glucose tolerance during extradural analgesia. Br J Anaesth 1982; 54: 325-31.

8 Cowen MJ, Bullingham RES, Paterson GMC, et al. A controlled comparison of the effects of extradural diamorphine and bupivacaine on plasma glucose and plasma cortisol in postoperative patients. Anesth Analg 1982; 61: 15-8.

9 Holdcroft A, Hall GM, Cooper GM. Redistribution of body heat during anaesthesia. Anaesthesia 1979; 34: 758-64.

10 Jenkins J, Fox J, Sharwood-Smith G. Changes in body heat during transvesical prostatectomy. Anaesthesia 1983; 38: $748-53$.
11 Brandt MR, Fernandes A, Mordhorst R, Kehlet $H$. Epidural analgesia improves postoperative nitrogen balance. Br Med J 1978; 1: 1106-8.

12 Kehlet H, Brandt MR, Prange Hansen A, Alberti KGMM. Effect of epidural analgesia on metabolic profiles during and after surgery. Br J Surg 1979; 66: 543-6.

13 Simmons $M$, Phillips $P$, Doctor $U$, Liehr $P$. The effect of two introperative heat-conserving methods on orthopedic patients receiving regional and general anesthesia. $J$ Post Anes Nursing 1992; 7: 170-5.

14 Cullen BF, van Belle $G$. Lymphocyte transformation and changes in leukocyte count: effects of anesthesia and operation. Anesthesiology 1975; 43: 563-9.

15 Rem J, Saxtrup Nielsen $O$, Brandt MR, Kehlet $H$. Release mechanisms of postoperative changes in various acute phase proteins and immunoglobulins. Acta Chir Scand 1980; 502: 51-6.

16 Hjortso N-C, Andersen T, Frosig F, Neumann P, Rogon E, Kehlet $H$. Failure of epidural analgesia to modify postoperative depression of delayed hypersensitivity. Acta Anaesthesiol Scand 1984; 28: 128-31.

17 Whelan P. Morris PJ. Immunological responsiveness after transurethral resection of the prostate: general versus spinal anaesthetic. Clin Exp Immunol 1982; 48: 611-18.

18 Erskine $R$, Janicki $P K$, Ellis $P$, James MFM. Neutrophils from patients undergoing hip surgery exhibit enhanced movement under spinal anaesthesia compared with general anaesthesia. Can J Anaesth 1992; 39: 905-10.

19 Moudgil GC. Anaesthesia and leucocyte locomotion. Can J Anaesth 1992; 39: 899-904.

20 Welborn LG, Rice LJ, Hannallah RS, Broadman LM, Ruttimann UE, Fink $R$. Postoperative apnea in former preterm infants: prospective comparison of spinal and general anesthesia. Anesthesiology 1990; 72: 838-42.

21 Spence AA, Smith G, Harris $R$. The influence of postoperative analgesia and operative procedure on postoperative lung function: a comparison of morphine with extradural nerve block. Anaesthesia 1970; 25: 126.

22 Spence $A A$, Smith $G$. Postoperative analgesia and lung function: a comparison of morphine with extradural block. Br J Anaesth 1971; 43: 144-8.

23 Jayr C, Mollie A, Bourgain JL, et al. Postoperative pulmonary complications: general anesthesia with postoperative parenteral morphine compared with epidural analgesia Surgery 1988; 104: 57-63.

24 Hedenstierna G, Lofstrom J. Effect of anaesthesia on respiratory function after major lower extremity surgery. Acta Anaesthesiol Scand 1985; 29: 55-60.

25 Hole A, Terjesen T, Breivik $H$. Epidural versus general anaesthesia for total hip arthroplasty in elderly patients. Acta Anaesth Scand 1980; 24: 279-87.

26 McKenzie PJ, Wishart HY, Dewar KMS, Gray I, Smith G. Comparison of the effects of spinal anaesthesia and gen- 
eral anaesthesia on postoperative oxygenation and perioperative mortality. Br J Anaesth 1980; 52: 49-54.

27 Laaksonen VO, Arola MKJ, Hannelin M, Inberg $M V$, Kivisaari A. Effect of anaesthesia on the incidence of postoperative lower limb thrombosis. Ann Chir Gynaecol Fenn 1973; 62(5): 304-17.

28 Thorburn J, Louden JR, Vallance R. Spinal and general anaesthesia in total hip replacement: frequency of deep vein thrombosis. Br J Anaesth 1980; 52: 1117-21.

29 Modig J, Borg T, Bagge L, Saldeen T. Role of extradural and of general anaesthesia in fibrinolysis and coagulation after total hip replacement. Br J Anaes 1983; 55: 625-9.

30 McKenzie PJ, Wishart HY, Gray I, Smith G. Effects of anaesthetic technique on deep vein thrombosis. $\mathrm{Br} \mathrm{J}$ Anaesth 1985; 57: 853-7.

31 Davis FM, Laurenson VG, Gillespie WJ, Foate J, Seagar $A D$. Leg blood flow during total hip replacement under spinal or general anaesthesia. Anaesth Intens Care 1989; 17: 136-43.

32 Davis FM, Laurenson VG, Gillespie WJ, Wells JE, Foate $J$, Newman $E$. Deep vein thrombosis after total hip replacement. J Bone Joint Surg (Br) 1989; 71-B: 181-5.

33 Mitchell D, Friedman RJ, Baker'III JD, Cooke JE, Darcy $M D$, Miller III MC. Prevention of thromboembolic disease following total knee arthroplasty. Clinical Orthopaedics and Related Research 1991; 269: 109-12.

34 Stafford-Smith $M$, Hall RI. Complications following total knee arthroplasty - does the anaesthetic technique make a difference? Can J Anaesth 1990; 37: S163.

35 Prins $M H$, Hirsh $J$. A comparison of general anesthesia and regional anesthesia as a risk factor for deep vein thrombosis following hip surgery: a critical review. Thrombosis and Haemostasis 1990; 64(4): 497-500.

36 Jorgensen LN, Rasmussen LS, Nielsen PT, Leffers A, Albrecht-Beste $E$. Antithrombotic efficacy of continuous extradural analgesia after knee replacement. Br J Anaesth 1991; 66: 8-12.

37 Ghoneim MM, Hinrichs JV, O'Hara MW, et al. Comparison of psychologic and cognitive functions after general or regional anesthesia. Anesthesiology 1988; 69: 507-15.

38 Hughes $D$, Bowes $J B$, Brown $M W$. Changes in memory following general or spinal anaesthesia for hip arthroplasty. Anaesthesia 1988; 43: 114-7.

39 Asbjorn J, Jakobsen BW, Pilegaard HK, Blom L, Ostergaard A, Brandt MR. Mental function in elderly men after surgery during epidural analgesia. Acta Anaesthesiol Scand 1989; 33: 369-73.

40 Williams-Russo P, Urquhart BL, Sharrock NE, Charlson $M E$. Post-operative delirium: predictors and prognosis in elderly orthopedic patients. JAGS 1992; 40: 759-67.

41 Gelb $A W$, Nielson WR, Merchant RN, Penny FJ, Manninen $P H$. Spinal vs general anesthesia: longterm intellec- tual and memory effects in a geriatric population. Anesth Analg 1989; 68: S99.

42 Berggren D, Gustafson Y, Eriksson B, et al. Postoperative confusion after anesthesia in elderly patients with femoral neck fractures. Anesth Analg 1987; 66: 497-504.

43 Santos $A L$, Gelperin $A$. Surgical mortality in the elderly. Journal of the American Geriatrics Society 1975; XXIII(1): 42-6.

44 McLaren AD, Stockwell MC, Reid VT. Anaesthetic techniques for surgical correction of fractured neck of femur. Anaesthesia 1978; 33: 10-14.

45 White IWC, Chappell WA. Anaesthesia for surgical correction of fractured femoral neck. Anaesthesia 1980; 35: 1107-10.

46 Mann RAM, Bisset WIK. Anaesthesia for lower limb amputation. Anaesthesia 1983; 38: 1185-91.

47 McKenzie PJ, Wishart HY, Smith G. Long-term outcome after repair of fractured neck of femur. $\mathrm{Br}_{\mathrm{r}} \mathrm{J}$ Anaesth 1984; 56: $581-5$

48 Valentin N, Lomholt B, Jensen JS, Hejgaard N, Kreiner $S$. Spinal or general anaesthesia for surgery of the fractured hip? Br J Anaesth 1986; 58: 284-91.

49 Davis FM, Woolner DF, Frampton C, et al. Prospective, multi-centre trail of mortality following general or spinal anaesthesia for hip fracture surgery in the elderly. $\mathrm{Br} \mathrm{J}$ Anaesth 1987; 59: 1080-88.

50 Hosking MP, Lobdell CM, Warner MA, Offod KP, Melton III $L J$. Anaesthesia for patient over 90 years of age. Anaesthesia 1989; 44: 142-7.

51 Wedel DJ, Krohn JS, Hall JA. Brachial plexus anesthesia in paediatric patients. Mayo Clin Proc 1991; 66: 583-8.

52 Sculco TP, Ranawat $C$. The use of spinal anesthesia for total hip-replacement arthroplasty. J. Bone Joint Surg (Am) 1975 Mar; 57(2): 73-7.

53 Keith I. Anaesthesia and blood loss in total hip replacement. Anaesthesia 1977; 32: 444-50.

54 Rose $D K$, Cohen $M M$, Rogers $K H$. Is recovery room morbidity related to the surgical procedure? Can J Anaesth 1991; 38 (4): A50.

55 Cohen MM, Duncan PG, Pope WDB. Tweed WA, Biehl $D$. Canadian four-centre study of anaesthetic outcomes: I. description of methods and patient population. Can J Anaesth 1991; 38 (4): A51.

56 Duncan PG, Cohen MM, Tweed WA, Pope WDB, Biehl $D$. Canadian four-centre study of anaesthetic outcomes: III. results for inpatients. Can J Anaesth 1991; 38 (4): A53.

57 Beattie WS, Buckley DN, Forrest JB. The incidence of postoperative nausea and vomiting in women undergoing laparoscopy is influenced by the day of menstrual cycle. Can J Anaesth 1991; 38: 298-302.

58 Beattie WS, Lindblad T, Buckley DN, Forrest JB. Menstruation increases the risk of nausea and vomiting after laparoscopy: a prospective randomized study. Anesthesiology 1992; in press. 


\section{Comparaison de l'anesthésie régionale et de l'anesthésie générale en orthopédie}

L'anesthésie régionale, a semble-t-il, plus à offrir à la chirurgie orthopédique périphérique qu’à toute autre discipline chirurgicale. ${ }^{1}$ Cependant, la croyance générale non démontrée, selon laquelle l'anesthésie régionale serait supérieure à la générale se perpétue. Au moins un auteur proclame bien haut les " avantages habituels " de la régionale sans toutefois les spécifier. ${ }^{2}$ Les chirurgiens et internistes affirment sans ambages que l'anesthésie rachidienne diminue le risque. En réalité, les bénéfices de l'anesthésie régionale occupent une plus grande place dans notre imagination que dans la littérature médicale.

Le choix d'une technique anesthésique repose sur plus d'un facteur. Premièrement, on peut choisir une technique parce qu'on la connait; ou encore, on la favorise parce qu'elle est nous plus familière; quelquefois on choisit une technique moins connue pour le maintien ou le perfectionnement de notre compétence ou pour l'enseigner. Ceci est vrai pour toutes les techniques et rien ne devrait s'opposer à ce qu'on les varie pour maintenir un niveau de compétence acceptable.

Deuxièmement, on peut choisir une technique pour ses effets spécifiques comme la sympathectomie ou encore pour obtenir la collaboration active d'un patient pendant lintervention. La technique choisie peut nous permettre d'eviter une manoeuvre qui augmenterait le risque de complications, e.g., on évite la régionale dans les coagulopathies, mais on la préfère lorsqu'on anticipe des difficultés à l'intubation.

Les arguments les plus irrésistibles en faveur de la régionale proclament que nos patient évoluent plus favorablement et qu'ils sont moins sujets à certains types de complications. Ce sont là malheureusement les zones où l'évidence est la moins convaincante. Bien que l'anesthésie régionale puisse nous permettre quelquefois d'éviter certains évènements fâcheux, ${ }^{3}$ ceci ne se traduit pas toujours par une influence appréciable sur le pronostic. Une analyse de la littérature comparant l'anesthésie générale à la régionale dans une grande variété d'interventions a démontré que a diminution de lincidence de la thrombose profonde était le seul avantage de la régionale sur la générale. ${ }^{4}$ On réclame pour la régionale une réduction de la morbidité dans les domaines métabolique, immunologique, pulmonaire, une diminution de lincidence des thromboses veineuses profondes et le maintien des fonctions cognitives. Les discussions portent aussi sur supériorité de la régionale sur la générale dans certains groupes d'âge, la diminution de la perte sanguine ou la prévention des nausées et des vomissements.

\section{La fonction métabolique}

Plusieurs études des effets de la régionale sur le métabolisme ont été menées en chirurgie pelvienne ou abdominale et ne s'appliquent pas d'emblée à l'orthopédie. Il n'est pas inutile d'en tenir compte. Pendant la chirurgie, le bloc épdiural réalisé avec un anesthésique local atténue la réponse hyperglycémique ${ }^{5}$ et l'augmentation du cortisol plasmatique. ${ }^{6}$ Cette inhibition persiste en postopératoire, si le bloc est maintenu; cependant la réponse insulinique à l'hyperglycémie persiste pendant la période postopératoire, et elle est indépendante du choix de l'anesthésique. ${ }^{7}$ L'utilisation de la diamorphine extradurale est associée à une baisse de la glycémie et de la cortisolémie. ${ }^{8}$ Sous péridurale, la chaleur corporelle est redistribuée vers la périphérie, ce qui a pour effet d'abaisser la température centrale; 9,10 il se pourrait que l'affaiblissement de la sécrétion de cortisol atténue aussi l'augmentation de l'activité métabolique nécessaire pour le retour à la température corporelle normale. Une réduction globale du déficit azoté a été enregistrée sur une période de cinq jours après l'anesthésie épidurale comparativement à l'anesthésie générale à l'halothane" ce qui plaide en faveur d'une réduction du catabolisme. La lipolyse diminue aussi dans les 24 premières heures postopératoires, un effet qui disparaît presque complètement dès qu'on permet aux effets de l'épidurale de se dissiper. ${ }^{12}$

Dans une étude concernant l'orthopédie, les patients récupérant d'une anesthésie générale avaient à leur admission à la salle de réveil des températures inférieures à celles qui ont été mesurées chez des patients opérés sous épidurale; ceci pourrait s'expliquer par la plus longue durée des interventions sous anesthésie générale; ${ }^{13}$ les autres indicateur métaboliques n'ont pas été recherchés. 


\section{La fonction immunitaire}

En étudiant le retentissement de l'anesthésie et de la chirurgie sur la transformation lymphocytaire et la leucocytose, Cullen et Van Belle ${ }^{14}$ ont trouvé une suppression qu'ils croyent proportionnelle au degré de traumatisme chirurgical, tout en étant indépendante du type d'anesthésie, qu'elle soit générale ou régionale. Linterprétation de leurs données est compliquée par la variété des interventions étudiées et linclusion dans l'étude de cas où l'anesthésie régionale était utilisée pour des épreuves diagnostiques et le traitement de la douleur chronique.

L'épidurale pour l'hystérectomie abolit l'hyperglycémie et l'hypercortisolémie constatées dans le groupe anesthésie générale; cependant la protéinémie en phase aiguë a subi les mêmes variations dans les deux groupes. ${ }^{15}$ Lhypersensibilité à retardement n'est pas différente entre les deux types d'anesthésie ${ }^{16}$ en chirurgie abdominale. Cependant, après une RTUP sous anesthésie rachidienne, la baisse de la leucocytose est moins marquée de même que la réponse aux mitogènes. ${ }^{17}$ Pendant l'arthroplastie totale de la hanche, l'anesthésie générale à l'halothane ou l'isoflurane inhibe la chimiotaxie des neutrophiles, ${ }^{18}$ ce qui n'est pas le cas pour la rachidienne.

Dans un éditorial publié par le Journal canadien d'anesthésie, Moudgil ${ }^{19}$ évoque avec clarté les difficultés rencontrées in vivo et in vitro pour évaluer les fonction immunitaires, et la complexité des influences dans une contexte clinique. A ce moment-ci, il existe certes de l'évidence suggérant une interaction entre anesthésie, chirurgie et système immunitaire, mais la nature précise et l'importance de cette influence demeure douteuse.

\section{La fonction pulmonaire}

A l'exception de l'embolie pulmonaire (voir plus loin), les complications pulmonaires ne constituent pas un problème majeur en chirurgie orthopédique périphérique. Chez les patients dont la commande ventilatoire est défectueuse (e.g., apnée du sommeil, ex-prématurés à risque pour l'apnée d'origine médicamenteuse), on peut trouver des indications spécifiques pour l'anesthésie régionale, ce qui permet d'éviter l'utilisation de sédatifs pour l'anesthésie ou l'analgésie. Les avantages rapportés proviennent d'observations cliniques et non d'études contrôlées comparatives. ${ }^{20}$ Les études qui rapportent le maintien ou le retour précoce à la normale des volumes pulmonaires portent surtout sur des interventions abdominales, ${ }^{21-23}$ et ne montrent pas d'avantages uniformes pour l'analgésie ou l'anesthésie régionale. Une étude compare l'anesthésie rachidienne pour l'arthroplastie totale de la hanche ou du genou à la générale pour l'arthroplastie totale de la hanche. ${ }^{24}$ Le groupe rachianesthésie accuse une augmentation du gradient alvéolo-artériel et une baisse de la $\mathrm{PaO}_{2}$; ce phénomène pourrait être dû à la dépression respiratoire causée pas la morphine sousarachnoïdienne administrée au groupe rachianesthésie; ou encore il pourrait refléter une différence dans l'importance de la micro-embolisation pulmonaire entre la chirurgie du genou et celle de la hanche.

Des observations plus prévisibles nous proviennent de Hole et al. ${ }^{25}$ et McKenzie et al. ${ }^{26}$ Hole a trouvé qu'au premier et au troisième jour postopératoire, la $\mathrm{PaO}_{2}$ est plus élevée chez les patients qui avaient subi l'arthroplastie totale de la hanche sous anesthésie épidurale que sous anesthésie générale. Chez les patients qui subissent une réduction chirurgicale de fracture de la hanche, McKenzie constate une baisse immédiate significative de la $\mathrm{PaO}_{2}$ après l'anesthésie générale contrairement à la rachianesthésie. Cependant, on n’a pas encore démontré l'influence de ces changements sur le pronostic et il est prématuré de concéder sur ces données la supériorité à l'une des techniques.

\section{La thrombose veineuse profonde}

Les études qui rapportent une diminution de la thrombose veineuse profonde sous anesthésie régionale, particulièrement dans les cas de fractures et d'arthroplasties totales de la hanche, méritent une révision en profondeur. On attribue ce bénéfice à plusieurs causes dont le maintien de la ventilation spontanée permettant un retour veineux sans obstruction, ${ }^{27}$ l'augmentation de la déformation des globules rouges pendant la rachianesthésie, ${ }^{28}$ le maintien de la fibrinolyse ${ }^{29}$ ou à une association de ces facteurs. ${ }^{30}$ Le débit sanguin au membre inférieur a été mesuré pendant et après la rachianesthésie et l'anesthésie générale mais l'influence de la technique anesthésique n'est pas évidente. ${ }^{31}$ Les mêmes auteurs ont trouvé par la suite que l'anesthésie générale avait une activité thrombogénique significative sur un modèle de régression logique qui prédit lincidence de la thrombose veineuse profonde après arthroplastie totale de la hanche. Dans l'arthroplatique totale du genou, ni Mitchell et al. ${ }^{33} \mathrm{ni}$ StaffordSmith et al ${ }^{34}$ ne trouvent de différence pour l'incidence de la thrombose veineuse profonde chez les patients recevant une anesthésie générale associée à une prophylaxie antithrombique comparativement à l'épidurale avec prophylaxie antithrombique débutée après l'opération.

Linitiation d'une prophylaxie adéquate et précoce est probablement vitale. Prins et Hirsh ${ }^{35}$ ont réalisé une revue critique portant sur l'évidence de l'activité antithrombique de l'anesthésie régionale. Sans remettre en cause l'évidence de la réduction de la thrombose veineuse, ils commentent que les études concernaient toujours des patients qui n'avaient pas reçu de prophylaxie préopératoire. L'incidence de la thrombose veineuse profonde, bien que diminuée sous anesthésie régionale, atteignait un taux inacceptable de $29-40 \%$. Ils énoncent que l'anesthésie 
régionale ne doit être considérée comme un substitut à une prophylaxie anthrombique primaire.

Une étude subséquente par Jorgensen ${ }^{36}$ au cours de laquelle on utilise des bas élastiques compressifs après remplacement total du genou montre une incidence de $17 \%$ dans le groupe épidurale contre $59 \%$ dans le groupe anesthésie générale.

\section{Fonction intellectuelle}

La détérioration intellectuelle est un sujet dinquiétude majeure chez le vieillard en pleine possession de ses facultés. Les complications se situent entre la perte de concentration, la dépression, la perte de mémoire de courte durée à la démence pouvant tourner au délire. L'étiologie de la l'affaiblissement intellectuel est compliquée et peut provenir de maladies pré-existantes, de complications périopératoires, de lhospitalisation elle-même, et des effets des analgésiques et autres médicaments administrés en postopératoire. L'incidence rapportée varie de $7 \%$ à $25 \%$. Hole et al. ${ }^{25}$ trouvent un affaiblissement intellectuel important dans le groupe anesthésie générale avec des changements prolongés pendant plusieurs mois, alórs qu'ils ne les retrouvent pas dans le groupe régionale. Cependant d'après Ghoneim, il n'y a pas d'évidence pour démontrer que le choix de l'anesthésie influence de quelque façon la condition mentale à la période postopératoire immédiate et après trois mois. ${ }^{37} \mathrm{Il}$ trouve une baisse immédiate de la fonction de reconnaissance des mots 24 heures après une arthroplastie de la hanche sous rachianesthésie; ce qui ne survient pas après l'anesthésie générale. Cette différence ne se retrouve plus après 48 heures et après une semaine. ${ }^{38}$ Même dans la prostatectomie, intervention considérée à risque pour la dysfonction cognitive postopératoire, Asbjorn et al. ${ }^{39}$ ne trouvent pas de différence entre régionale et générale; les deux groupes subissent des baisses significatives de performance mesurées par des tests psychologiques au 4ième jour postopératoire suivies de récupération complète.

Parmi les patients qui sont opérés pour une arthroplastie bilatérale totale de genou sous épidurale, $41 \%$ développent du délire, la plupart dans le $\mathbf{4 8}$ heures qui suivent la chirurgie. On ne trouve pas de différence entre deux types d'analgésie administrés par cathéter épidural en continu: bupivacaïne avec du fentanyl et du fentanyl seul. ${ }^{40}$ Bien que incidence semble très élevée, il faut mentionner que le diagnostic est basé sur les critères DSM III $\mathrm{R}$ appliqués à l'aveugle par des investigateurs; la moitié seulement des patients qui rencontrent ces critères étaient classifiés comme délirants par le personnel soignant. Dans une étude examinant spécifiquement mémoire et quotient intellectuel après l'arthroplatie totale du genou chez les patients âgés, on ne trouve pas de différence entre anesthésie rachidienne ou générale après trois mois. ${ }^{41}$
Dans leur tentative didentification des prédicteurs de la confusion mentale postopératoire chez le fracturé de la hanche, Berggren et al. ${ }^{42}$ trouvent que les antécédents dépressifs et l'usage de médicaments possèdant une activité anticholinergique (e.g., anti-dépresseurs, tricycliques, neuroleptiques, médicaments agissant sur la fonction vésicale) sont des prédicteurs valides, alors que la technique anesthésique (épidurale ou générale à l'halothane) ne l'est pas.

\section{L'anesthésie et la personne âgée}

Santos et Gelperin ${ }^{43}$ faisaient la remarque en 1975 que la mortalité chirurgicale gériatrique diminuait sensiblement et qu'on ne devait pas priver la personne âgée du traitement chirurgical en raison de son âge. Plusieurs études subséquentes se sont intéressées aux techniques anesthésiques susceptibles de réduire la morbidité et la mortalité gériatrique.

Malgré certaines études selon lesquelles la rachianesthésie pourrait être associée à un taux de mortalité moins élevé, ${ }^{44}$ plusieurs études subséquentes n'ont pu confirmer ces conclusions ${ }^{45-50}$ chez des patients opérés pour la réduction chirurgicale d'une fracture de la hanche ou pour une arthroplastie totale de la hanche. En partie, ce changement apparent reflète une durée d'observation plus longue. On voit souvent une réduction à court terme du taux de la mortalité avec une convergence de la mortalité totale après 2-3 mois.

\section{L'anesthésie régionale pédiatrique}

Malgré les commentaires fréquents diffusés dans les conférences d'actualisation et les résumés de présentation sur les avantages potentiels de l'anesthésie régionale chez l'enfant, on trouve très peu de références dans la littérature sur le devenir et la technique anesthésique utilisée. Beaucoup de facteurs associés avec la morbidité et la mortalité chez l'adulte et la personne âgé ne se retrouvent pas chez l'enfant.

Cependant, l'utilisation des techniques régionales, réalisée de façon sécuritaire et dans des conditions acceptables, peut produire une bonne analgésie postopératoire sans le besoin de recourir aux opiacés après certains types de chirurgie ambulatoire, ce qui a pour effet principal de diminuer les nausées et les vomissements. ${ }^{51}$

\section{Les pertes sanguines}

On présente souvent la diminution du saignement opératoire comme un avantage de l'anesthésie régionale pour l'arthroplastie totale de la hanche et la réduction chirurgicale des fractures de la hanche. Cependant, une seule étude ${ }^{44}$ parmi les cinq études révisées ${ }^{26,30,44,47}$ conclut à une diminution significative de la perte sanguine peropératoire pour la réduction des fractures de la hanche. 
Dans l'arthroplastie totale de la hanche, trois études révisée ${ }^{28,29,52}$ montrent une diminution significative de la perte sanguine peropératoire alors qu'une seule ${ }^{25}$ n'en démontre pas.

Comme pour la thrombose veineuse profonde, la ventilation mécanique pourrait jouer un rôle dans l'augmentation de la perte sanguine pendant l'arthroplastie totale de la hanche. Les patients sous anesthésie générale en ventilation spontanée ont des pertes sanguines totales comparables à celles des patients sous rachianesthésie; dans les deux cas la perte sanguine a été moindre que sous ventilation mécanique. ${ }^{52} \mathrm{Il}$ a été impossible de trouver une comparaison directe entre l'anesthésie générale associée à l'hypotension délibérée et l'anesthésie rachidienne ou épidurale. On n'a trouvé aucun avantage pendant l'arthroplastie totale du genou, ${ }^{33-34}$ ce qui na rien de surprenant étant donné l'utilisation fréquente du garrot.

\section{Les nausées et les vomissements}

Bien que l'incidence des nausées et vomissements soit moindre après les interventions orthopédiques qu'après la chirurgie gynécolique et viscérale, ${ }^{54}$ on présente souvent cette diminution comme un avantage de l'anesthésie régionale. Au moins une étude réalisée après l'arthroplastie totale de la hanche confirme cet énoncé. ${ }^{25}$ On rapporte toutefois une grande variabilité entre hôpitaux de cet effet indésirable. ${ }^{55,56} \mathrm{Si}$ on doit tenir compte d'autres facteurs potentiels aggravant comme les variations hormonales cycliques, ${ }^{57,58}$ les difficultés d'élaboration d'un protocole approprié sont plutôt décourageantes.

\section{Conclusion}

Il apparaît difficile de produire un argument convaincant (à partir de la littérature faisant état du pronostic à long terme) qui favoriserait l'anesthésie régionale sur la générale en chirurgie orthopédique. En ce qui concerne la thrombose veineuse profonde, c'est l'attention médicale portée au patient qui doit être modifiée plutôt que la technique anesthésique. Les avantages de l'anesthésie régionale pourraient ne pas faire long feu et subir l'inondation de la multitude des autres facteurs reconnus, aussi bien en ce qui concerne la perte sanguine que le délire postopératoire. Même les nausées et vomissements ne sont pas réduits de façon évidente par l'usage des techniques régionales. La persistence de cette prétendue supériorité de l'anesthésie régionale peut refléter le dicton qui énonce que les mythes ont la vie dure, ou encore résulter du fait qu'on ne s'est pas encore posé les bonnes questions qui nous permettraient délucider une impression clinique répandue. La dernière question demeure un défi.

\section{Références}

(Voir page R107) 